\title{
INNOVATIVE ACTIVITIES OF AGRICULTURE IN UZBEKISTAN
}

\author{
Rustamova Dilsahon Djuraevna \\ PhD (Economics), Senior Lecturer, Department of Agribusiness and Investment Activities, \\ Makhmudov Odil Xalmirzaevich \\ PhD (Economics), Department of Agribusiness and Investment Activities, \\ Yuldashev Akmaljon Mexmonovich \\ Senior Lecturer, Department of Agricultural Machines and Technical Service
}

Andijan branch of Tashkent state Agrarian University, Uzbekistan, Andijan city

DOI: https://doi.org/10.31435/rsglobal_ws/30112019/6780

\section{ARTICLE INFO}

Received: 20 September 2019

Accepted: 18 November 2019

Published: 30 November 2019

\section{KEYWORDS}

agriculture, innovative management, efficiency, economic, technological, model, farm enterprise, dehkan farm, crop yield, modeling, innovative development, animal production, crop production.

\section{ABSTRACT}

This article reflects the issues of sustainable development of the agricultural sector of Uzbekistan, the innovative activity of the sector, as well as issues of effective management.

Citation: Rustamova Dilsahon Djuraevna, Makhmudov Odil Xalmirzaevich, Yuldashev Akmaljon Mexmonovich. (2019) Innovative Activities of Agriculture in Uzbekistan. World Science. 11(51), Vol.3. doi: 10.31435/rsglobal_ws/30112019/6780

Copyright: (C) 2019 Rustamova Dilsahon Djuraevna, Makhmudov Odil Xalmirzaevich, Yuldashev Akmaljon Mexmonovich. This is an open-access article distributed under the terms of the Creative Commons Attribution License (CC BY). The use, distribution or reproduction in other forums is permitted, provided the original author(s) or licensor are credited and that the original publication in this journal is cited, in accordance with accepted academic practice. No use, distribution or reproduction is permitted which does not comply with these terms.

At present, a new paradigm of world economic development is emerging through the use of innovation. Uzbekistan cannot deny these processes and needs to ensure the intensification of innovative processes in all sectors of the economy, including agriculture. These issues were also highlighted in the Decree of the President of the Republic of Uzbekistan dated February 7, 2017, No. P-4947 "On the Strategy of Action for the Further Development of the Republic of Uzbekistan".

The transition to an innovative way of economic development depends not only on the problems accumulated in the agricultural sector of the Uzbek economy, but also on the need to address the major challenges facing the sector. In modern conditions innovative activity is the main factor of agricultural development. The maximum use of this factor is the only way to ensure the sustainable development of the agricultural sector in the country. In the context of accelerated socio-economic transformations and globalization of the global economy, our country should, in the short term, accelerate the transition to innovative path of agricultural development, to revive this strategically important sector of the economy on a qualitatively new technological basis. Otherwise, the agricultural sector lags behind in development and cannot sustain itself.

Until now agricultural development has been and remains one of the most important priorities. After all, the efficiency of agricultural production, ensuring economic and food security of the country, improving the well-being of the rural population and the population of the country are inseparably linked with the constant improvement of the fertility and quality of our land.

Sustainable development of the agricultural sector of Uzbekistan is largely dependent on the effectiveness of innovative activities. This, in turn, will strengthen Uzbekistan's integration into the world market. 
The economies of the countries, depending on the type and level of development, are generally divided into countries that are specialized in the production of raw materials, industrial economies, post-industrial economies, mixed economies, and innovative economies or knowledge economies.

Innovative economies are the most advanced type of economy and are characterized by an educated society. Currently, various mechanisms and institutional structures, ie the national innovation system, are being formed for the wider implementation and effective use of science and technology. Technological modernization of agriculture is one of the priorities in the stabilization of agriculture. The only technique aimed at further improving the management of agricultural machinery enterprises, increasing their efficiency and profitability, modernization, technical and technological re-equipment of the industry, production of modern high-performance, competitive machinery and equipment for the agroindustrial complex. mini-technologist among domestic entrepreneurs and foreign companies following the results of the exhibitions in 2015 enabled, compact equipment and agricultural machinery to purchase a total contract value of more than 145 billion UZS 1180 and Contracting signed the protocols.

More than 195 companies from 24 countries, including China, South Korea, France, Italy, Germany, Belgium, Austria, Bulgaria, Belarus, Netherlands, Iran, Russia, and Turkey participated in the exhibition Uzbekistan Agrominitech Expo 2015. I did. It includes a wide range of products for the processing of agricultural products, packaging mini-technologies, equipment for livestock, poultry, beekeeping and horticulture, mini-equipment and equipment for food production, horticulture and viticulture, chemical products and services for greenhouses. was shown.

Today, Uzbekistan has all the necessary socio-economic bases for deepening the innovation process and strengthening the innovation base. However, there are problems with the way of innovative development of the agrarian sector, or in other words, the implementation of innovative projects in one or even several farms, because: firstly, farms and agro-processing entities are currently ordering research and research. insufficient participation in financing; Secondly, the economic entity cannot independently carry out research and development of advanced innovation technologies; thirdly, lack of knowledge of agricultural producers and processors for the use of new technologies and new varieties, they need to use the services of scientists and specialists, and farmers face some difficulties in the processing and sale of products; Fourthly, the insufficiency of the developers' demand for innovation development by scientists of higher education and research institutions is not well established; Fifth, irresponsibility of some agricultural producers.

In the context of the ongoing socio-economic changes and inter-country integration in the country, it is necessary to move the agricultural sector and rural areas, including rural infrastructure, to a new path of innovative development. This path will help to raise the status of the village on the basis of modern technology.

The transition to innovative development of Uzbekistan's economy has been considered as a priority. It is estimated that the innovation in the agrarian sector of Uzbekistan is 1-2\% of the GDP and less than 50-60\% in the rural infrastructure.[10]

The use of state-of-the-art technology and technology in production gives the following opportunities [12]: the production of competitive, world-class products; Expansion of financial capabilities of the enterprise due to the significant reduction in the cost of production and expansion of opportunities; savings of raw materials and resources; reduction of negative impact on environment, etc. If these techniques and technologies are innovative, that is, they are based on previously unused applications and ideas, then their economic and social significance is even greater. The introduction of innovative technologies into production allows to achieve higher efficiency than the technologies used in this field.

Increasing the economic efficiency of agricultural production requires rational use of agricultural production, wide use of scientific and technological progress, introduction of new highly efficient machines and equipment, new methods of agricultural and zootechnical methods, organization of labor and production. He does. In order to select and implement the most effective methods and techniques, it is necessary to check them in advance, to assess their organizational and economic value. In agricultural enterprises, this assessment is based on the performance criteria of the national economy, that is, the increase in labor productivity, and the increase in labor productivity is reflected in the increase in production and national income. This is achieved by increasing the production volume and improving the quality of products in each agricultural enterprise, reducing the cost of live and productive labor per unit of production, and increasing the net income. The following basic indicators are used to determine the economic efficiency of new methods and methods of production in agricultural enterprises [13]: the amount of high quality products per one hectare and per head; labor productivity; product cost; net profit and profitability; capital investments and their compensation. These indicators are closely related and 
mutually reinforcing. The higher the quantity, the better the quality, the higher the productivity, the lower the cost, the higher the profit and the higher the profitability, the less capital is required and the faster the cost, the higher the cost-effectiveness of new methods and techniques. . New methods and techniques are optimized if needed. This optimization allows you to choose the most effective from a wide variety of options, taking into account the opportunities available to solve business tasks.

Prospects for further strengthening of food security of the country, expansion of production of ecologically pure products, significant increase of export potential of agrarian sector through consistent development of production by deepening structural changes in agriculture, uninterrupted supply of population with raw materials, processing industry. one of the most important tasks for the fall. In this regard:

- Expansion and optimization of potato, vegetable, melons, fodder and oilseeds, new intensive gardens and vineyards by reducing the area of cotton and cereals;

- Improvement of reclamation condition of irrigated lands, development of melioration and irrigation facilities, introduction of high-tech, water and resource-saving agricultural technologies, use of high-performance equipment;

- Expansion of scientific-research work on creation and introduction of new selection varieties and high-yielding breeds of agricultural crops resistant to diseases and pests, in accordance with local climatic and environmental conditions;

- construction, reconstruction and modernization of existing processing plants for food and packaging products on the basis of deep processing of agricultural products;

- development of diversified farms engaged in the production, processing, procurement, sale, construction and provision of agricultural products;

- development of infrastructure for storage, transportation, sale of agricultural products, agrochemical, financial and other modern market services;

- take systematic measures to mitigate the negative impacts of global climate change and the Aral Sea crisis on agricultural development and the activities of the population.

Improvement of the theoretical and methodological foundations of various forms of ownership and ownership, the types of entrepreneurship and free market relations that allow them to operate freely in the industry, in order to fulfill the above objectives and to keep pace with the requirements of market economy laws. The introduction of scientific and technological achievements, the introduction of new technologies, advanced technologies, limited land and so on It is desirable to identify ways of full and effective use of water resources, permanent and changing capital and labor resources in the short and long term, and to identify ways to maximize profits on the basis of cost savings, labor productivity improvement, and farmers' and employee incentives.

Issues of innovative development are of particular relevance for Uzbekistan, because innovative development through rapid and efficient use of new resource-efficient, advanced technologies will ensure rapid economic growth, while preserving the environment.

Comparison of different technologies with modern technologies shows that the minimum land cultivation, saving current and investment costs, can produce a much lower cost and generate more than one hectare of land per crop.

However, technology change is a complex process that requires a systematic approach, knowledge of all the changes that occur in an enterprise's technological system, from traditional technologies to new resource-saving technologies. In this regard, it is necessary to develop process algorithms for introducing technological and organizational and economic innovations in agricultural enterprises.

\section{REFERENCES}

1. Appendix 1 to the Decree of the President of the Republic of Uzbekistan dated February 7, 2017 № PF4947 "On the Strategy of Action for the Development of the Republic of Uzbekistan" "Strategy of Action for the Five Priorities for the Development of the Republic of Uzbekistan for 2017-2021". Lex.uz.

2. Vakhobov A.R. The organization and development of field-based methods in the development of the economy. Autoorepf. dis. candy. econ. nauk. - T.: NIIRR v APK, 1997. - 7 p.

3. Berkinov BB, Tashmatov R.K. Directions for the Development of Farm Services Infrastructure in Uzbekistan. - T.: TSIU, 2007 - 23 p.

4. Mirzaev KD. "Methodological basis for improving the efficiency of agroservice services" dissertation, Samarkand, 2011, - 200 b.

5. Pardayev MK, Pardaev O.M. Improvement of organizational and economic mechanisms of using innovation in economic development of Kashkadarya region // Modernization of national economy on the basis of innovative development: problems, solutions and perspectives. - 2015, $22 \mathrm{p}$. 
6. Murodov Ch. Formation of a market infrastructure in rural areas // Economic Bulletin of Uzbekistan. Tashkent, 1999. - No. 3.2 - 4 b.

7. Khushmatov N., Fayzullaeva T. "Agricultural Service Networks and Basics of Farm Development" // Economy and Classes Substvennikov. - Tashkent, 2004. №1. -46 b.

8. Farmonov T.Kh. Prospects for Farm Development. - Tashkent: "Generation of the New Century", 2004. - 30 p.

9. Choriev K A. Formation of market infrastructure - the guarantee of deepening economic reforms // Basic directions of deepening market reforms and rural infrastructure development: Collection of Republican scientific-practical seminars. - Tashkent: UzBIITI, 1998. - B.15.

10. Khamraeva S.N. Innovative development of rural infrastructure. Monograph - Tashkent: 2017 - 73 pages.

11. Agriculture of Uzbekistan. The State Committee of the Republic of Uzbekistan on Statistics. Tashkent - 2017

12. Mambetnazorov B.B. K, peculiarities of modernization and diversification of production at agricultural enterprises // Problems of modernization and development of innovative management activity in the agroindustrial complex. Proceedings of the Republican scientific-practical conference. -T .: TDAU, 2014.- 32 pages.

13. Ikramova S.A. and others. Modern conceptual bases of development of agro-economy of the republic. // Problems of modernization and development of innovative management activities in the agro-industrial complex. Proceedings of the Republican scientific-practical conference. -T .: TDAU, 2014.- 46 pages. 